\title{
Forskning
}

\section{er ikke sannhet, men fortellinger}

\author{
Da hun hadde bestått en opptaksprøve på kunstlinjen, begynte moren å gråte - av skuffelse. \\ Christine Laine ble lege og sjefredaktør for Annals of Internal Medicine i stedet.
}

Det er tidlig en søndag morgen i et vinterkaldt Trondheim. Christine Laine kommer gående ned landgangen fra Hurtigruten med sin mann. De har hver sin gigantiske koffert, nesten så stor som en amerikakiste. Hun smiler lett når hun ser meg, men selv en fersk kliniker ser at noe har plaget henne i natt. Det var umulig ikke å legge merke til at de begge var gråbleke.

- Jeg visste det ville bli trøbbel da kapteinen sa på høyttaleren at det «sikkert er best å få seg litt søvn allerede nå, ettersom de neste timene kan bli litt tøffe». Koffertene fløy i lugaren, og alt som var løst falt på gulvet, forklarer hun mens hun fekter med armene og fasinasjonen ser ut til å ha vunnet over de norske bølgene.

Christine Laine er sjefredaktør i et av verdens mest prestisjefylte medisinske tidsskrifter. Annals of Internal Medicine er med i en celeber gruppe av tidsskrifter som oftest kalles «de fem store». På folkemunne kalles de Annals. Som amerikanere flest ville hun gjøre noe stort av turen til det lille landet, og tok like godt Hurtigruten fra Bergen til Trondheim. Anledningen for Trondheimsbesøket var Tidsskriftets årlige møte for faglige medarbeidere. Fremtiden for vitenskapelig publisering var temaet, og Laine er ansatt i tidsskriftkolossen nettopp for å bringe unge tanker til et stort publikum.

Hun er en liten, nett dame, har ingen kraftig stemme, og er egentlig ingen typisk folketaler. Idet hun går på scenen, skjer det en teknisk glipp.

- Det var ikke med vilje, men jeg liker ikke dette uansett, kan man så vidt høre henne si når hun oppdager at mikrofonen ikke er slått på idet hun går på scenen på Rica Nidelven hotell.

Etter at mikrofonen er slått på, har hun hele salens oppmerksomhet. Særlig når hun på et sted i talen blir glødende engasjert. Det er når hun snakker om PLOS. PLOS er det mest anerkjente arkivet som publiserer forskning som er tilgjengelig gratis for leserne. De refereres til svært hyppig fra andre tidsskrifter, og har dermed oppnådd høy akademisk prestisje. Artiklene publiseres enkeltvis som de er, uten noen redaksjonell sammensying i et tidsskrift eller liknende.

- Vi skal ikke være et arkiv, men skal jobbe litt som kuratorer på et museum. Vi skal sette sammen de beste samlingene av kunnskap for våre lesere. Når du går på Munchmuseet, vet du at du får se et godt utvalg av Munchs arbeider. Når du går til

\section{«Jeg vet ikke helt hvorfor jeg ble lege. Jeg liker vitenskap, men også folk og historier. Medisin er et fag der vitenskapen blir involvert i folk og folks historie»}

PLOS, er det som å komme til arkivet i museet - massevis av malerier, plassert uten noen rekkefølge og ikke presentert på en fornøyelig måte. Men du kan slumpe til å finne en god artikkel.

- Hvem leser PLOS egentlig? Jeg kjenner ingen. Når du velger å publisere noe, må du også lage en kontekst rundt det. Kanskje skriver du en lederartikkel, kanskje lager du et undervisningsopplegg, du endrer presentasjonen og du velger tidspunkt. Kurators oppgave er mer enn å velge ut, det handler også om å lage en sammenheng. Kuratering er altså mye mer enn å filtrere. Arkivet er ikke særlig interessant hvis ikke noen kuraterer det.

\section{Det heldige uhellet}

Det var egentlig ikke medisin i det hele tatt som fasinerte den unge Christine. Da hun skulle begynne på college, var planen å velge kunst. Det må hun ha fra faren, som etter mange år som ingeniør ble skulptør.

- Jeg besto første opptaksprøve, og var klar for neste del. Pappa var veldig glad, men mamma gråt. Hun ble faktisk veldig oppskaket, hun ville ikke ha en datter som skulle bli en sultende kunstner.

Christine Laine tok i stedet fagene skriftlig fremstilling og biologi på college. Allerede da var hun en hardtarbeidende ung kvinne, og gikk ut av college med strålende resultater. Det var nok til å gå videre på medisin.

- Jeg vet ikke helt hvorfor jeg ble lege. Jeg liker vitenskap, men også folk og historier. Medisin er et fag der vitenskapen blir involvert i folk og folks historie. Jeg likte å skrive, men trengte noe å skrive om. Man kan ikke skrive om skriving.

Overgangen til å jobbe med medisinsk journalistikk omtaler hun som et sammenfall av tilfeldigheter. Et heldig uhell.

- Mange tror at jeg planla å bli redaktør, men det var en tilfeldighet. Da vi flyttet til Philadelphia, arbeidet jeg med et forskningsprosjekt og traff en av redaktørene i Annals. De manglet noen til å skrive om generell indremedisin, så da begynte jeg som assisterende redaktør.

Som redaktør bruker hun de samme delene av hjernen som hun gjorde som forsker. Forskjellen er at hun sitter på andre siden av bordet.

- Det er en fin side å sitte på fordi du slipper unna søknader om forskningsmidler. Og du skriver refusjonsbrev i stedet for å motta dem. Jeg savner ikke forskning så mye som jeg savner det kliniske arbeid og interaksjonen med pasientene.

Laine er ikke den typiske redaktøren av det ærverdige tidsskriftet. Støvet tørkes jevnlig av bildene på veggen i konferanserommet i redaksjonene - menn med grått hår, og en seriøs mine. Lengst til høyre henger et bilde av en mann og en kvinne. Ekteparet var redaktører sammen, og er det nærmeste en kvinne har kommet sjefsstolen tidligere. Men kanskje enda viktigere enn kjønn er det faktum at redaktørene alltid har hatt årelange tillitsverv i American 


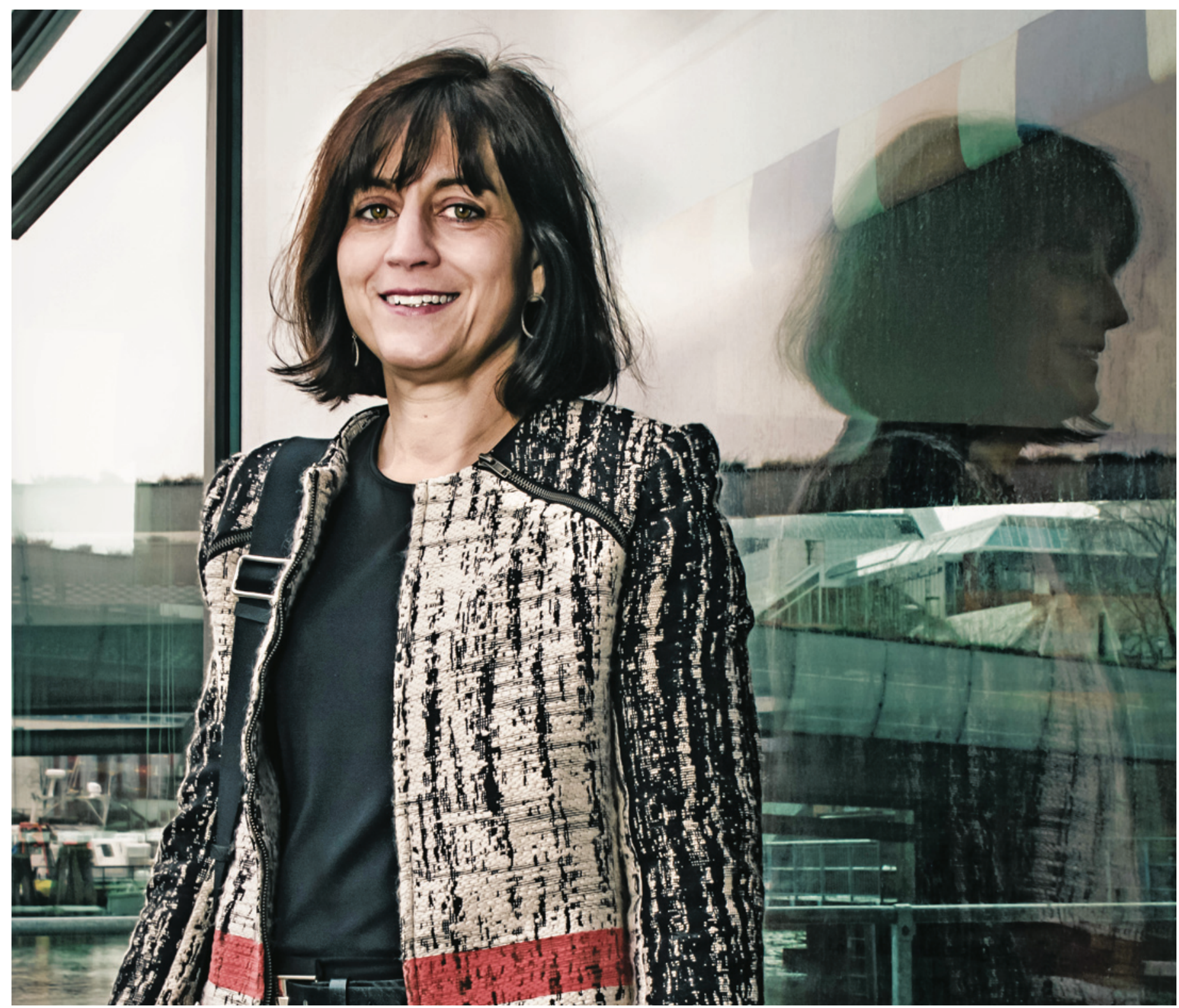

Foto Ole Kristian Losvik

\section{Christine Laine}

Født i USA

- Skriftlig fremstilling og biologi ldouble major) ved Hamilton College, New York i 1983

- Lege i 1987 ved Stony Brook, New York

- Master of Public Health fra Harvard University i 1992

- Redaktørstillinger i Annals of Internal Medicine fra 1995

- Sjefedaktør i Annals of Internal Medicine fra 2009

- Seniorvisepresident i American College of Physicians siden 2009
College of Physicians (ACP), og for nesten alle var det deres siste jobb før pensjonisttilværelsen.

- Jeg var veldig overrasket over at jeg fikk stillingen, og det tror jeg mange andre var også. Folk som kjenner meg godt, visste at jeg kunne gjøre jobben, men det var en enorm endring for organisasjonen. Men American College of Physicians så det nok som en fordel å bryte opp sementen litt.

\section{Livet på House of God}

Christine Laine tok deler av spesialiseringen på Beth Israel Hospital. Sykehuset er for mange best kjent som House of God i den satiriske romanen med samme navn av Stephen Bergman.

- Alle folkene i House of God var fremdeles der. De hadde andre navn, men de var der ennå. Den aller beste karakteristikken er «little old ladies» (LOL), og sykehuset er fullt av LOLs, de er typisk jødiske, veldig små, de har minst fem navn, og sitter på sengen mens de holder hardt på håndvesken. Og de slår deg virkelig hvis du prøver å ta den fra dem. Historien er ganske sann, og personlighetene, alt det gode og også det dårlige er overdrevet, men i grunnen sant.

Selv om redaktøren er opptatt av å fortelle gode historier, er hun ikke overbevist om at forskningsformidling skal ta med seg alt av virkemidler fra skjønnlitteraturen.

- Overdrivelse er nok mer nyttig når man skal beskrive menneskelig atferd enn når man skal formidle forskning. Selv om vi hele tiden ser at forskere overdriver når de rapporterer resultater fra egen forskning og betydningen av den, er det ikke nyttig 
for andre enn industriens markedsføringsavdelinger. Men når man skal få frem poenger som ikke er vitenskapelige, kan det være nyttig å tillate en friere og mer skjønnlitterær stil fordi det gjør det lettere for leserne å huske.

Det store traumet i Annals er en artikkel om levetid hos Oscar-vinnende skuespillere. Annals publiserte studien som viste at skuespillere som fikk Oscar, hadde en overlevelsesgevinst på fire år sammenliknet med dem som ble nominert, men ikke vant prisen. Selv om historien var godt fortalt, og nådde langt, så er den dessverre overdrevet.

- Den gikk gjennom en rigorøs redaksjonell prosess, med lange og grundige diskusjoner. Jeg angrer egentlig ikke på at vi publiserte den, den skadet ingen, og den er det mest nyttige eksemplet jeg har når jeg underviser om kritisk lesing av artikler. Noen ønsker nok at vi ikke hadde publisert artikkelen.

- Det er blitt en veldig viktig artikkel for undervisning av metode, og har skapt utrolig mye diskusjon. Budskapet står jo fast: Bekreftelse fra fagfeller ser ut til å ha helsefordeler - også blant eliten i samfunnet.

\section{Forskning er ikke sannhet}

Hvor ofte har man ikke tenkt at hunden likner på eieren sin. Men likner redaktøren på tidsskriftet sitt? Man kan jo gjøre seg noen tanker når man sitter med en korrekt, nøktern, saklig dame som snakker med små bokstaver. Og er sjef for et tidsskrift som er akkurat sånn.

Redaktøren er derimot vennlig. Tidsskriftet hennes er kjent for å være blant verdens mest rigide. De bruker ikke fagfeller til å vurdere metode, men sju fast ansatte statistikere. Ikke alle forfattere synes det er noen fordel at alle sju går gjennom alle manuskripter som skal publiseres. Og de gir seg ikke før alle er enige. Første manuskonferanse er om innholdet, og hvis manuset blir akseptert der, kommer det videre til metodekonferansen.

- Vi bruker ikke fagfellevurderere til å vurdere metode, det gjør våre egne redaksjonelle medarbeidere ansatt for det formålet. Men fagfellevurdererne må vite om den er klinisk relevant. Hvis du skal oppdage metodiske svakheter eller forskningsjuks, kan vi ikke ha et system som er avhengig av fagfellevurderinger. Disse kommer nok ikke til å forsvinne, men tidsskriftene må foreta grundige metodologiske vurderinger selv.

- Forskning er ikke sannhet, men du forteller hva du har gjort og hva du fant. Hvis andre vil gjenta det du gjorde, så skal det være mulig. Hvis ikke er det en kommentar. Redaksjonen skal bistå leserne med å forstå innholdet $i$ artikkelen. Noen ganger har studier flere vesentlige svakheter, men vi vet at ingen kommer til å utføre noen bedre studie av akkurat det fenomenet noen gang. Da må vi publisere den sammen med advarsler om hva svakhetene består i.

Hun innser at det kan være ganske så omstendelig å komme gjennom hos Annals, og tror kanskje noen vegrer seg for å sende inn. Hun mener at forfatterne av de $7 \%$ av artiklene som kommer gjennom har grunn til å være fornøyd.

- Jeg kan ikke komme på noe bedre sted å publisere artikler, fordi hvis man kommer gjennom metodologisk gjennomgang, så er det bra, vi gjør veldig få korreksjoner, når vi ser bort fra den Oscar-artikkelen. Redaksjonsprosessen vår kalles ofte tortur i USA. Vi prøver å endre det, men bare med å bli raskere og vennligere.

- Det vanskeligste i mitt profesjonelle liv for tiden er at vi er en liten redaksjon, få mennesker med svært forskjellige personligheter. Noen ganger oppnår vi ikke konsensus. Det tapper meg for energi når vi ikke blir enige. Noen i redaksjonen er veldig

\section{«Forskning er ikke sannhet, men du forteller hva du har gjort og hva du fant»}

entusiastiske, mens andre er redd for at himmelen skal falle ned, slik som da vi publiserte artikkelen om Oscar-vinnere. Vi bruker kallenavn fra Ole Brumm på statistikerne. «Tigergutt» er alltid entusiastisk, mens «Tussi» kan godt komme til å si at selv om vi gjorde alt rett, så ville det være feil.

Det mest kontroversielle hun har skrevet, er en nylig publisert kommentar om våpenkontroll.

- Jeg sa til kollegene at jeg skulle skrive en kommentar om våpenkontroll, og at den ikke kom til å bli godt mottatt overalt. Alle var med. Noen mener kanskje at å være perfekt er å ikke publisere noe som gjør noen sint. Kommentaren var politisk og emosjonell.

- Man må ta risikoen når det er nyttig. Historisk er jeg usikker på om noen av de tidligere redaktørene i Annals ville skrevet og publisert en kommentar om våpenkontroll. Manges liv påvirkes av våpen, men forskere vil ikke skrive om våpenkontroll fordi de er redd for at finansieringen til prosjekter vil forsvinne. Det er risikabelt å ta opp temaet våpenkontroll hvis man er offentlig finansiert. Jeg er redd de har rett.

Tilknytningen til American College of Physicians gjør nok at tidsskriftet er litt mindre frittalende enn for eksempel Lancet.

- Lancet er politiske med store bokstaver. Vi er også politiske, men viser det med litt mindre bokstaver. Lancet er uavhengig av profesjonelle organisasjoner, men ikke uavhengig av kommersielle krefter. Jeg nyter å ha en ikke-kommersiell organisasjon bak meg. Men jeg har ikke noe trykk på meg for å publisere artikler fra annonsører, og er lykkelig for det. Jeg føler meg veldig fri.

\section{Balansekunst}

Den store konflikten i tilværelsen er mellom jobben og resten av livet. Annals har en liten redaksjon, og det kan være tider der alle må ta et skippertak.

- Man må jobbe hardt når det er påkrevet. Når man ikke trenger å jobbe, må man dra hjem og være sammen med familien.

Å oppnå balanse er det jeg strever mest med $i$ livet. Selv om ungene er blitt mer uavhengige, så har foreldrene mine blitt eldre. Jeg jobber hardt, mannen min jobber hardt. Men det er mye bra også. Når vi begge jobber, har familien en trygg økonomi. Når jeg foreleser i Kina, så kan jeg ta med barna. Sønnen min lærte også noe av å spise middag med kinesiske tidsskriftredaktører.

- Søvn er ikke så viktig for meg. Min mann og jeg har et veldig balansert forhold. Han er sjef for indremedisin på et sykehus. Til tross for et ekstremt krevende arbeidsliv klarer vi å dele ansvaret hjemme.

I tillegg til mann og to barn har familien hund. Og så omsorgen for Annals, da.

- Annals er mitt fjerde barn. Jeg må alltid ha øynene på det, jeg glemmer det aldri og jeg elsker å se det vokse og ha suksess. Men akkurat som ungene kan det noen ganger være irriterende, problematisk og holde meg våken om natten. Forskjellen er at barna mine er der permanent, mens Annals skal jeg en gang forlate.

Hun mener fordelen med balansekunsten er at hun aldri kjeder seg. Så snart hun merker kjedsomheten komme, er det alltid noe å gjøre. Dra hjem, eller dra på sykehuset. Så hva med fritid? Joda, hun leser, ser film, reiser, går på ski og er med barna. Og noen ganger finner hun også mannen underholdende.

- Frykter du kjedsomhet?

- Det jeg frykter mest er å miste uavhengigheten min, men dernest er jeg redd for å kjede meg.

- Hva gjør du når du kjeder deg?

- Jeg har aldri kjedet meg, men jeg har vært sliten.

- Hvis du er virkelig utslitt, da?

- Da trener jeg. Der ser du, du fikk virkelig ikke noe uventet ut av dette intervjuet. Jeg er ikke særlig interessant. Men takk, det var utrolig at du ville bruke to timer med meg.

\section{Ole Kristian Losvik}

losvik@gmail.com

Hjertemedisinsk avdeling

St. Olavs hospital 